\title{
The Legally Permissible Traditional Customary Uses of Wildlife and Forests under Kenyan Law
}

\author{
Nixon Sifuna \\ Africana Consultants, PO Box 5496-30100, Eldoret, Kenya \\ Email:nsifuna@yahoo.com
}

How to cite this paper: Sifuna, N. (2021). The Legally Permissible Traditional Customary Uses of Wildlife and Forests under Kenyan Law. Open Journal of Forestry, 11, 292-314.

https://doi.org/10.4236/ojf.2021.113018

Received: April 28, 2021

Accepted: July 5, 2021

Published: July 8, 2021

Copyright (อ 2021 by author(s) and Scientific Research Publishing Inc. This work is licensed under the Creative Commons Attribution International License (CC BY 4.0).

http://creativecommons.org/licenses/by/4.0/

(c) (i) Open Access

\begin{abstract}
Kenya like most of sub-Saharan Africa is reliant predominantly on agriculture and natural resources; which include land, water, minerals and fisheries, but the most dominant of which are wildlife and forestry. Unlike minerals which are by law vested in the government and can only be extracted by it and not the citizenry, wildlife and forestry are resources that the citizens may utilize in their day to day lives to meet their needs. Apart from their consumptive uses, there are also non-consumptive uses and values of wild animals and forests; such as their intrinsic ecological value as gene banks, as well as their scenic value for viewing. These are essentially conventional values and uses. They are largely formal and universal ones that are universally obtaining across the world irrespective of the levels of civilization or cultural identity, and are even compatible with modernity. Apart from these, there are some wildlife and forestry uses which are unique to the typical African way of life as part of old traditional customs that have existed from earlier times. These are what are in this paper referred to as "traditional customary uses". These uses are largely informal, rudimentary and archaic. They are nevertheless critical in the endemic African way of life and represent the inextricable rudimentary technologically bereft relationship between the African people and their natural resources. Under the country's existing laws, some of these uses are prohibited and criminal sanctions prescribed to enforce their proscription, hence cannot be enjoyed or practiced. There are however others that the law has either expressly allowed, or not prohibited, hence may be lawfully enjoyed or practiced. These are what this paper has referred to as the legally permissible traditional customary uses; and are the ones that are its subject. As for wildlife, in the year 1977, the Kenya Government by a Legal Notice in the Kenya Gazette imposed a ban on all forms of hunting of wildlife. The ban is still in force. This therefore means that hunting is illegal, as legal prohibition has in effect prohibited all and any form of off-take or killing of wildlife. By implication therefore, under Kenyan law, only non-con-
\end{abstract}


sumptive uses of wildlife may be enjoyed, and not the consumptive ones. These include viewing as well as socio-cultural and spiritual uses. In Kenya therefore, the only permissible traditional customary use of wildlife is its nonconsumptive use for socio-cultural and spiritual purposes; subject of course to the existing legal prohibition on witchcraft under the Witchcraft Act (Cap 67 Laws of Kenya). This piece of legislation has prohibited the practice and promotion of witchcraft. This in effect means that the socio-cultural and spiritual uses of wildlife though legally permissible, will be enjoyed, provided it is not for witchcraft purposes. With regard to forests, this author has identified the following five as their legally permissible traditional customary uses under Kenyan law: Socio-cultural and spiritual (consumptive and non-consumptive) use, other than for witchcraft; use in herbal folk medicine, other than for witchcraft; use for human food and livestock fodder; use for firewood; and use as raw material in construction and traditional craft. Notably, in Kenya, traditional customary use is subject to the existing legal prohibition on witchcraft. Further, while it is the legally permissible use category that is the focus of this paper, the author nevertheless discusses the prohibited traditional customary uses as well. This paper is based on literature survey as well as data obtained from the author's previous research whose primary data and findings have been published in recent times. It also draws from the documented research and diverse documented views of other commentators on the subject.

\section{Keywords}

Traditional Customary Uses, Legally Permissible, Wildlife, Forests, Witchcraft, Witchcraft Act, Kenyan Law, Taina

\section{General Introduction and Background}

\subsection{General Introduction}

This paper is on the legally permissible traditional customary uses of wildlife and forests, i.e. those uses that may be enjoyed under Kenya's existing law. While the main thrust is on these permissible uses, the paper nevertheless also examines the prohibited traditional customary uses as well. These two use categories are discussed in the part below; beginning with the prohibited uses, then moving to the legally permissible ones. The paper is divided into five parts. Part One is an introduction, that introduces the paper and gives a background to the subject matter; thereby laying a background for the discussion in the subsequent parts. It first generally introduces the structure of the paper. It then makes a geographical description of Kenya. It thereafter discusses the country's wildlife and forest estates, and finally proceeds to give a brief overview of the uses of wildlife and forests. Part Two examines Kenya's policy and legislative framework on wildlife and forestry. Part Three discusses the traditional customary uses of wildlife and forests that are under Kenya's existing laws prohibited, while Part Four discusses 
legally permissible uses of wildlife and forests under Kenyan law. Part Five is the conclusion part that summarizes the discussion in the entire paper, and makes conclusions that tie up the issues discussed. The paper is based on literature survey as well as data obtained from the author's previous research whose primary data and findings have been published; and also draws from the documented research as well as diverse documented views of other commentators on the subject.

\subsection{Background}

\subsubsection{The Geographical Location and Description of Kenya}

The Republic of Kenya has a total land area of approximately 582,600 km² (Ogendo, 1972), and with a population of over 47 million people (KNBS, 2019 National Population Census Report). It is located on the Eastern side of the African continent, and lies astride the equator, being almost bisected by it. It is bounded by the following countries: Uganda in the West, South Sudan in the North-west, Ethiopia in the North, Somalia in the East, and Tanzania in the South (Ruigu, 1988). Lying to the East of the country is the Indian Ocean. Kenya is also a riparian of two of Africa's big lakes, namely, Lake Turkana, and Lake Victoria which is the world's second largest fresh water lake after Lake Superior of North America. Her altitude varies from sea level to over 5000 meters, with temperature and rainfall being significantly affected by the altitude. Another notable aspect of Kenya's physical characteristics is her three main drainage systems, namely: the coastal lowlands system, where rivers drain into the Indian Ocean; the Rift Valley system, where streams feed into a chain of lakes within the Rift Valley; and the Lake Victoria system, where a group of rivers to the west flow into Lake Victoria (Reuben, 1973). The lake staddles the territory of Kenya as well as those of Uganda and Tanzania.

\subsubsection{The Historical Relationship of the Kenyan People with Their Wildlife and Forests}

The Kenyan people have a historical relationship with the country's wildlife and forests; a relationship that is resilient and one that has existed from time immemorial and through the generations to the present and hopefully to posterity. Before arrival of the colonialists, the indigenous African communities co-existed with wildlife and forests, utilizing them as they needed, and in accordance only with African customary practices and values (Muriuki, 1996). These communities hunted and killed wild animals for subsistence, and also harvested plants and forests for food and other uses such as clothing, bedding, cultural purposes, spiritual purposes, etc. Many ethnic groups also had specific animals and trees that were totem and believed to be sacred and which were not to be harvested or which could only be utilized for prayers or medicinal purposes (Sifuna, 2012). Generally, there were traditional customs, rules, taboos, beliefs and practices of the various ethnic groups relating to these resources (ODA, 1996). With the advent of colonialism, things changed dramatically when the colonial governments 
started imposing stiff laws on wildlife and forestry utilization. These were on hunting and wildlife products, as well as harvesting and utilization of forests and other forest products such as honey. Takirambudde (1988) has observed that colonialism in Africa created "a new legal order to replace the traditional structures and ideology”. This account is also true of Kenya (Sifuna, 2009; Sifuna, 2012).

\subsubsection{Kenya's Wildlife and Forest Estates}

Wildlife and forests are valuable natural resources with several values to humanity. Kenya's wildlife and forestry are not only resource sectors, but also large economic sectors contributing billions to the country's gross domestic product (GDP) and providing thousands of direct and indirect jobs (Sifuna, 2009). They are also the backbone of tourism, which is one of Kenya's largest foreign exchange earners. Tourists visit the country, to mainly enjoy its wildlife, forests as well as its coastal sand beaches. With regard to wildlife, the country has one of the most abundant and most diversified wildlife estates in the world, with many species of wild animals, ranging from small to large charismatic mammals, from herbivores to carnivores; and with some animals that are rare and not found in many places in the world (Sifuna, 2009; Sifuna, 2012). As for forestry, although with a forest cover of only about 7.4 percent of the land cover, the country's forests are very rich in diversity and range from indigenous montane forests such as the bamboo, to tall closed canopy deciduous equatorial forests, to the coastal mangrove forests; with over 300 of them being gazetted forests under state protection (KFS, 2018a).

The country's economy like most of her sub-Saharan Africa counterparts is reliant predominantly on agriculture and natural resources. These resources include land, water, minerals, fisheries, wildlife and forests; the most dominant being wildlife and forests. Kenya is one of the countries with abundant and richly varied wildlife and forestry resources, with a wildlife endowment surpassing most places on earth (Sifuna, 2012). Given their economic importance in the national economy, wildlife and forests are sectors in their own right. With each having its own policy framework, its own law, its own institutional and administrative structures, as well as its own pool of expertise. As already noted above, other than Agriculture, Kenya's other leading foreign exchange earner is tourism particularly wildlife-based tourism. Besides wildlife, the country's natural tourist attraction is its forests.

\subsubsection{A Brief Overview of the Uses of Wildlife and Forests}

Like many other resources, wildlife and forests need to be of some value or use to humans; as the term resource refers to anything for human use and benefit (Wantrup, 1952). However, unlike minerals which are by law vested in the government and can only be extracted by it and not the citizenry, wildlife and forests are resources that the citizens may utilize in their day to day lives to meet their needs. Even under Kenyan law, minerals are for exclusive exploitation by the state (Section 4 of the Mining Act of 2012, Cap 306 Laws of Kenya), while 
other natural resources such as wildlife and forests may be utilized by the citizenry in their day to day life to meet their needs. Indeed these two resources, as already observed in this paper, have several beneficial uses to humans.

These usefulness of wildlife and forests may be their consumptive uses, nonconsumptive uses or merely their intrinsic value such as the role in biodiversity as gene banks, or their scenic value for viewing. Besides, some wildlife and forestry uses are unique to the typical African way of life as part of old traditional customs that have existed from earlier times; as opposed to modern uses (Sifuna, 2012). That this paper refers to as "traditional customary uses". The phrase "traditional customary" is used in this paper to refer to long-established tradition in accordance with indigenous customs existing from ancient times. Although these uses are largely informal, rudimentary and archaic, they are nevertheless critical in the African life and represent the inextricable rudimentary technologically bereft relationship between the African people and nature. These are anthropologically unique to the traditional African way of life. Under the country's existing laws, some of these uses are prohibited and criminal sanctions prescribed for infraction; hence cannot be enjoyed or practiced. There are however others that the law has not prohibited, hence may be lawfully enjoyed or practiced. These are in this paper referred to as the "legally permissible traditional customary uses", and are the ones that are the subject of this paper. Notably, even these legally permissible uses are subject to Kenya's existing legal prohibition on witchcraft. In the context of this paper, the term "witchcraft" is used to refer to the malevolent invocation of evil spirits to cause harm to others, by bewitchment, black magic, sorcery, and wizardry.

\section{Kenya's Policy and Legislative Framework on Wildlife and Forests}

Kenya has an impressive policy and legislative framework on wildlife and forestry. The current policy on wildlife is the Wildlife Policy of 2020 (Sessional Paper No. 1 of 2020) (GOK, 2020a), and the National Wildlife Strategy 2030. On forestry, it is the National Forest Policy of 2014 (GOK, 2014), but there is also a Draft National Forest Policy 2020 (GOK, 2020b). There is also the Kenya Forest Service $3^{\text {rd }}$ Strategic Plan 2018-2022 (KFS, 2018b). In these policy instruments, the Kenya Government recognizes the respective importance of wildlife and forestry to the national economy as well as to its people. Notably, Kenya's Wildlife Policy and Forest Policy are in diametrical contrast. With regard to wildlife, only non-consumptive utilization is promoted, while with regard to forestry the policy recognizes and promotes non-consumptive as well as consumptive uses. It recognizes the intrinsic non-consumptive value of forests as well as the consumptive uses in terms of supply of wood forest products and supply of nonwood forest products. It further notes that these non-wood forest products are important to the livelihoods of the rural communities, and lists them as including gums and resins, honey, essential oils, frankincense, myrrh, fibres, medicinal 
and aromatic plants, dying and tanning materials (GOK, National Forest Policy, 2014). Wildlife commentators (e.g. Norton-Griffiths, 2000) have described Kenya's wildlife policy as being prohibitive of consumptive use.

As for the legislative framework, it comprises Acts of Parliament (also called statutes or primary legislation) as well as subsidiary legislation in the form of regulations and executive orders. This normative pyramid is of course peaked by the Constitution as the supreme law from which all the other laws derive legitimacy ${ }^{1}$; with the principal legislations being the Wildlife Conservation and Management Act of 2013 as amended in 2019 (also referred to as the WCMA), ${ }^{2}$ and The Forest Conservation and Management Act of 2016 (also referred to as The FCM Act). ${ }^{3}$ The WCMA of 2013 was promulgated in the year 2013 to replace the then Wildlife Conservation and Management Act 1989 (Cap 376 Laws of Kenya), ${ }^{4}$ and came into force on $10^{\text {th }}$ January 2014. It in its preamble states that it is "an Act of Parliament to provide for the protection, conservation, sustainable use and management of wildlife in Kenya". It then designates the Kenya Wildlife Service (KWS) as the governmental agency in charge of conserving and managing Kenya's wildlife. The FCM Act for its part was promulgated in the year 2016 to replace The Forests Act of $2005,{ }^{5}$ and came into force on $31^{\text {st }}$ March 2017. It in its preamble states that it is "an Act of Parliament to give effect to Article 69 of the Constitution with regard to forest resources; to provide for the development and sustainable management, including conservation and rational utilization of all forest resources for socio-economic development of the country". It then designates the Kenya Forest Service (KFS) the governmental agency in charge of conserving, protecting, controlling and managing all public forests. On general forestry, Article 69 (1) of The Constitution of Kenya 2010 obligates the State to work to achieve and maintain a tree cover of at least 10 percent of the country's land area. This Constitution in its preamble acknowledges the environment as the people's heritage that needs to be sustained for the benefit of future generations. It in the said Article 69(1) further obligates the state to ensure sustainable exploitation, management and conservation of the environment and natural resources, and ensure the equitable sharing of the accruing benefits.

Apart from Acts of Parliament, the other form of legislation is subsidiary legislation. This comprises regulations and executive orders issued by the executive arm of government for purposes of promoting the objectives of the statutes, operationalizing them, assisting in their implementation, or filling some gaps in them. These are issued pursuant to ministerial powers donated under the parent Act to officers, particularly the Cabinet Secretary in charge of the sector. One such with regard to wildlife is Legal Notice No. 120 of 1977 on wildlife hunting issued under the Wildlife Conservation and Management Act of 1976 (WCMA).

${ }^{1}$ The supremacy clause is in Article 2.

${ }^{2}$ Act No. 47 of 2013

${ }^{3}$ Act No. 34 of 2016

${ }^{4}$ Act No. 16 of 1989.

${ }^{5}$ Repealed by the FCM Act of 2016 
In respect of natural resources, such regulations or executive orders will usually relate to several issues, including management, access, and utilization. In the forestry sector an example of such executive order is the temporary moratorium on logging in public and community forests, that was imposed by the Kenya Government in February 2018, and which is still in force to date. It was issued by the Cabinet Secretary Ministry of Environment and Forestry. There had also been Legal Notice No. 171 of 1999 that had suspended timber harvesting in Kenya, and which ban was later on lifted. ${ }^{6}$

\section{The Legally Prohibited Traditional Customary Uses of Wildlife and Forests under Kenyan Law}

While there are many traditional customary uses of wildlife and forests, communities and their members can within the parameters of Kenya's existing laws lawfully enjoy in wildlife and forests, there are others that the law has prohibited and criminalized, with harsh penalties such as fines and imprisonment prescribed for infraction (Sifuna, 2021). That legal prohibition has by so prohibiting in effect proscribed and outlawed these uses. This author has identified three such uses, namely 1) wildlife Hunting; 2) use in the practice and promotion of witchcraft; and 3) human habitation of public forests. The legal prohibition on hunting has in effect prohibited all and any form of off-take or killing of wildlife. It means therefore that generally, only non-consumptive uses of wildlife may be exercised in Kenya, and not the consumptive ones. These legally permissible non-consumptive uses of wildlife are primarily, viewing as well as sociocultural and spiritual uses; and are discussed after these prohibited uses.

\subsection{Wildlife Hunting}

Africans have from time immemorial hunted and killed wildlife for their meat and other body parts such as their skins and hides. Among the Maasai of Kenya, an important part of the rite of passage for young adult men or 'morans' (meaning a Maasai warrior) is the killing of a lion as a demonstration of bravery (Kameri-Mbote, 2002). The morans then return home with the head of a lion as an exhibit, and thereafter the lion's mane is donned during ceremonies as head gear. Besides, wild animals have for long been an important source of food in many societies in the world, including Kenya where traditionally, many local communities have from time immemorial relied on wild animals for food. While this was the case then, in Kenya, hunting is by law prohibited and illegal (Sifuna, 2012). This legal prohibition was imposed in the year 1977 vide Legal Notice No. 120 of 1977, by which the Kenya Government banned all forms of hunting in Kenya. As already noted in this paper, the ban remains in force to date. This means that in Kenya, hunting has since 1977 remained illegal to date. There can therefore be no persons, group(s) of persons or communities lawfully practicing hunting in Kenya, even as a traditional way of life; which ironically also means ${ }^{6}$ Kenya Gazette Supplement No. 49 of 26 November 1999. 
Kenya has no hunters or hunter-gatherer communities (Sifuna, 2012). For that reason, until this ban has been lifted, no person(s), no group(s) of persons, and no community, can be lawfully practicing traditional or any form of hunting in Kenya. The ban having prohibited hunting, off-take or killing of wildlife, it means that only non-consumptive uses of wildlife may be exercised in the country, and not the consumptive ones. Therefore, for wildlife, there is only one permissible traditional customary use, namely, use for socio-cultural and spiritual purposes. Provided, as discussed below, the use is not for witchcraft purposes, because in Kenya, witchcraft is prohibited by the Witchcraft Act Cap 67 Laws of Kenya.

Admittedly, wildlife has always had several consumptive as well as non-consumptive traditional African customary use. The consumptive uses entail killing these animals then using their body parts or even eating their meat. There are many examples of such uses in Kenya. The hides of buffalos and giraffes are for instance used for making shields while that of the eland is used for making belts and ropes (Sifuna, 2012). The body parts of certain wild animals are used for making clothing as well as traditional ceremonial regalia. The Maasai morans still wear the lion's mane as a head dress in ceremonies. As already stated in this paper, the killing of a lion is required as part of the rite of passage for young adult men (called 'moran', and whose English translation is warrior) as a demonstration of bravery (Kameri-Mbote, 2002). The Samburu use antelope horns to make tobacco containers (Sifuna, 2012). Some of these traditional uses have been either curtailed or outrightly prohibited by the existing laws, for instance the aforesaid 1977 Kenya Government's legal ban on hunting and all forms of consumptive use of wildlife which has retained viewing and photography as the only lawful use of wildlife resources in Kenya. This ban has, for example, made it impractical to lawfully procure body parts of wild animals for traditional uses. There is however a variance between the law and practice in that there are communities in Kenya which still utilize or kill wild animals for cultural purposes, for instance the Maasai. Surprisingly, while the killing of lions is legally prohibited, such Maasai morans as kill lions in their rites of passage are not prosecuted. The reasons for this informal exemption could be that such killing of lions by the morans is considered a legitimate cultural practice, although illegal. A case of legitimacy overriding illegality.

\subsection{Use of Wildlife and Forests in the Practice and Promotion of Witchcraft}

Some trees and wild animals are believed, among certain communities, to be a source of magical powers and/or strength, which powers whether real or perceived make such animals to be of remarkable socio-cultural significance in the concerned communities. It is, for instance, believed in certain communities that "association between humans and wildlife believed to be mighty, powerful and full of strength would in turn instill similar values and attributes in such hu- 
mans" (Ipara, 2004). Animals such as the lion and leopard are in some communities still held as royal. There are communities in Kenya where wild animals are also used for worship and to appease ancestral spirits. In those communities there are people who turn to wildlife worship for spiritual nourishment as others go to church for the same reason. Besides, in many communities in Kenya, people have names adapted from certain animals considered to be totemic or royal (Kasere, 1996). In Kenya, the names include Simba (Lion), Kwach (Leopard), Nyang or Kwena (Crocodile), Wakhisi (Antelope), Ngari (Leopard), Ndwiga (Giraffe), Nguyo (Monkey), Mosonik (Baboon), Ngatia (Lion) and Njogu (Elephant) (Sifuna, 2009).

Apart from their spiritual uses, wildlife and forests have been reported to be used in witchcraft (Sifuna, 2012). Information from reports of respondents interviewed by this author in previous studies revealed that certain tree species and certain species of wildlife are associated with witchcraft. There are communities in western Kenya, for instance, that are reported to use in witchcraft, certain species of snakes, the leopard, the fox, the alligator (the monitor lizard), the monkey, and the owl. There are similar reports with some certain species of trees such as the fig tree and the baobab tree.

There are reports of witchcraft in the Mbuti Pigmies of Ituri Forest in the Democratic Republic of Congo (Yamaguchi, 2014; Harako, 1984). There are also across cultures, children's fairy tales and folklore, such as the ones dubbed "witches of the woods", about mystic forest witches. These are not only in Africa, but also in parts of Europe, America and Asia. Indeed forests are among the most common locus for fairy tales, due to the fact that forests are a realm beyond the humans' familiar territory; and the presumed habitat of mystic and mythical creatures. These imaginary creatures are in the form of monsters, dwarfs, giants, and other such creatures. There are also acts of witchcraft in Kenya's sacred forests such as the Kaya Forests at the Kenyan Coast, and the Njuri Ncheke shrines in Forests of Meru County in Eastern Kenya.

In Kenya, the practice of witchcraft is outlawed by the Witchcraft Act (Cap 67 Laws of Kenya). Interestingly, this is one of Kenya's briefest statutes, with only nine sections. The Act, which was promulgated in the year 1975 was adopted from the Witchcraft Act of 1924, a colonial legislation that came into force in 1924, and that was repealed by it. ${ }^{7}$ It in its preamble states that it is an Act of Parliament to consolidate and amend the law relating to witchcraft. Even though it does not define the word "witchcraft", it nevertheless criminalizes the practice and promotion of witchcraft. Under it for instance, it is an offence for anyone to practice or promote witchcraft, or be in possession of witchcraft paraphernalia. A proposal for a review of the Act was already made by the Kenya Law Reform Commission (KLRC) and it is long-overdue. Notably, African communities know what may be described as witchcraft i.e. the manevolent invocation of mystical and evil powers. Mbiti defined it as the use of mystical power to harm

${ }^{7}$ The Act was later amended and captioned in 1948 as Cap 25 of the Laws of the Colony. 
others in society (Mbiti, 1969). The colonialists associated it with the magic of the black African people variously referred to as "black magic". In criminalizing the practice and promotion of witchcraft, the Act has prohibited and prescribed criminal penalties for the following overt acts: "holding oneself out as a witchdoctor able to cause fear, annoyance or injury to another in mind, person or property, holding oneself out as being able to exercise any kind of supernatural power, witchcraft, sorcery or enchantment calculated to cause such fear, annoyance or injury; a witch-doctor supplying advice or article for witchcraft; using witch medicine with intent to injure others, possession of charms or other article usually used in witchcraft or sorcery, and attempting to discover crime by witchcraft. ${ }^{8}$ For these acts the Act provides for imprisonment ranging from one year to ten years. There is a danger of this Act being used to stifle the use of wildlife and forests in folk medicine as discussed later in this paper. Interestingly, there have recently been media reports of plans by a public university in eastern Kenya, to start an undergraduate degree course in Witchcraft ${ }^{9}$. Although it is unclear how credible those reports are, such a move will be a deviation from the dictates of the Witchcraft Act.

With an overly positivist judiciary together with an overzealous, corrupt, less literate, and socially insensitive police force such as Kenya's, the likelihood of using (actually misusing) the Witchcraft Act to stifle traditional African customary uses of wildlife and forests is even higher. This will then have the effect of clawing back the legality of many of these legally permissible traditional customary uses.

\subsection{Use of Wildlife in Folk Medicine}

Apart from the nutritional aspects of health, some wild animals are known to be of medicinal value with their body parts being used in the cure of diseases and the manufacture of drugs. Besides, many people in most rural areas in Kenya and Botswana rely on traditional medicine for their health care. Krunk (2002) for instance reports that several wild animals are popular for their supposed medicinal properties, with parts of some of them being used either in witchcraft or traditional medicine. These two uses cannot be practiced in Kenya, by reason of legal prohibition. Witchcraft as already stated in this paper is specifically prohibited in Kenya, by legislation (i.e. the Witchcraft Act Cap 67 Laws of Kenya). Even the use of wildlife in folk medicine, will be an illegality as it will require wildlife off-take i.e. the killing of wild animals; and which is prohibited. This prohibition is by dint of Legal Notice No. 120 of 1977 aforesaid, by which the Kenya Government slapped a ban on all forms of hunting of wildlife. The ban which has prohibited off-take, which involves the killing of wildlife, has not been lifted to date. This means that only non-consumptive uses of wildlife such as viewing and non-consumptive socio-cultural and spiritual uses may be exercised in Kenya, and not the consumptive ones. Therefore, for wildlife, there is only ${ }^{8}$ Section 2-5.

${ }^{9}$ https://nairobinews_nation.co.ke/editors-picks/machakos-university-fights-rumours-on-witchcraftdegree-course. 
one permissible traditional customary use, namely, non-consumptive socio-cultural and spiritual use. Provided, as discussed below, the use is not for witchcraft purposes, because in Kenya, the witchcraft vocation as well as its practice and promotion are prohibited by the Witchcraft Act.

This author has in an earlier study on Kenya and Botswana reported that wildlife in Kenya has medical values and parts of some wild animals are used for witchcraft, folk-medicine, and even modern medicine (Sifuna, 2009; Sifuna 2012). And further that:

"In both countries, certain wild animals for instance crocodile and rhinoceros, are popular for their supposed medicinal properties. Among the Yeyi of Botswana, burned ash of the rhino horn is sniffed to arrest nose-bleeding, while crushed powder of the horn mixed with milk is swallowed as a cure for asthma. In Kenya, rhino horn is exported to Asia for use as an aphrodisiac while crocodile body fat is applied on the body to cure skin ailments. In the Luhya community of western Kenya, meat of the private parts of a female crocodile cooked with any food is used as a love portion for adulterous husbands. Perhaps the most interesting revelation during the author's fieldwork for this paper was the use of the lion's body fat among the Samburu people of Kenya to keep away their creditors as it is believed that the scent evokes an aura of fear. Worth noting also in both countries is the use of the elephant's urine to cure asthma, and its semen to cure impotence among the old men. The other traditional use of wildlife parts in Botswana is the use of the Bushbaby by traditional healers. In an area believed to have sorcerers, the dried skin of the Bushbaby is burnt near a child and the child made to inhale the smoke. The smoke is believed to give protection to the child against the evil powers of the sorcerers. A portion of its dried meat cooked together with certain herbs and the soup given to an epileptic to drink over a prescribed period as a cure for epilepsy.

With the said Ban still in force, all uses as require the actual off-take or killing of wildlife, such as use in folk medicine, can under the law not be enjoyed in Kenya. This is unfortunate as most of the rural folk in Africa are known to rely on folk medicine as compared to biomedicine. Indeed traditional African customary uses of wildlife are currently threatened and seriously undermined by the modern way of life as well as the laws. This has resulted in local communities developing negative public attitudes towards wildlife, which they now perceive as a liability instead of a resource. The bone of contention being that, these local communities bear the burden of wildlife depredation (and predation), and wildlife also competes with them for resources (such as land, water, pastures, and fiscal resources), yet the people are not allowed to utilize wildlife for their daily needs.

\subsection{Use of Wildlife for Food and Nutrition}

Meat contains about 25 percent protein, as well as minerals, vitamins and fat (Caldecott, 1988). King and Burgess (2000) report that meat is a source of com- 
plete protein, iron, zinc, vitamins and fat. Game meat has for its part been reported to be generally higher in protein and nutritional value than meat from domestic stock (Shaw, 1985). Hakimzumwami (2000) for instance cites Central Africa where he says people favour game meat to domestic meat claiming that it has a better taste than the latter. It is even estimated that wild game can produce more meat than can domestic stock using the same area (Dasman, 1964). Indeed wildlife has for long been an important source of food in many societies in the world, including Kenya where traditionally, many local communities from time immemorial relied on wild animals for food. This is particularly true for the "hunting and gathering" phase of human life, where wildlife was a principal component of human diet as communities relied exclusively on game meat (meat from wild animals) and wild plants for their nutritional requirements (Dasman, 1964). Such communities were classified as "hunter-gatherer" and they obtained their food by hunting wild animals and game birds as well as collecting the honey of wild bees, wild fruits and edible roots. There are still many parts of the world where hunting is by law permitted and people still kill wild animals for meat. This is however not the case for Kenya as hunting has been, by law, prohibited and game meat is no longer lawfully part of the human diet. This legal prohibition as already stated in this paper, was imposed by Legal Notice No. 120 of 1977, by which the Kenya Government prohibited all forms of hunting, hence hunting is no longer legal in Kenya. After that ban, the Kenya Government in the year 2004 imposed another ban on the sale of game meat, except for crocodiles and ostrich for the reason of these two being game animals in which game farming, is, under the existing law, permitted. This ban was prompted by the poaching menace that had become rampant at the time; and it is still in force to this day. With the ban in force, wild game meat is prohibited, hence the only legit source of game meat are crocodile and ostrich farms. This is unlike previously when wild game meat was a delicacy that was being sold in some restaurants and hotels e.g. the Carnivore Restaurant in Kenya's capital city of Nairobi, that had a game meat menu. The most popular and common game meat at that time was from buffaloes, zebras and giraffes.

The current situation of game meat in the country, is in sharp contrast with the traditional African societies, especially among the hunter-gatherer peoples, where game meat was a major source of food and wild animals played a significant role in nutrition by providing humans with the body's nutritional requirements, especially protein (Sifuna, 2012).

As already observed in this paper, Kenya has through its policy acknowledged the importance of forests as a source of food. In its policy, the government notes that non-wood forest products are important to the livelihoods of the rural communities and lists some of these non-forest products as including "gums and resins, honey, essential oils, frankincense, myrrh, fibres, medicinal and aromatic plants, dying and tanning materials"; further notes that in times of food scarcity, some of these non-wood products are the main source of nutrition for commun- 
ities (GOK, National Forest Policy 2014).

\subsection{Human Habitation of Public Forests (Gazetted State Forests)}

Historically, forests have been reported to have been a habitat for humans and wildlife. In Kenya, whereas human habitation of forests existed in the pre-historic and antecedent primordial society, it is no longer practiced in the present day Kenya (Sifuna, 2021). There are two major causes of its abandonment. It is firstly due to the progressive socio-cultural transformations in the Kenyan society that have come with modernity and introduction of the lifestyles of western civilization. It is also largely due to legal prohibitions on it by the current forest laws, such as the FCM Act, that have prohibited and criminalized human habitation of gazetted state forests (also called public forests or government forests). The Act (Forest Conservation and Management Act, 2016) has in section 64 enumerated activities that are prohibited in these gazetted state forests. One of these prohibited activities is any person(s) being in there between the hours of 7 pm and $6 \mathrm{am}$, or erecting any building or home in there. The Act criminalizes these activities and prescribes a sentence of a fine of Kenya Shillings 100,000 $=$ (Equivalent to approximately 1000 USD) or six months imprisonment, or both. Aboriginal habitation claims by two of Kenya's traditional communities (the Ogiek and the Sengwer) have been dismissed by Kenyan courts. In dismissing the said claims the courts cited the prohibition under the country's forest law (Sifuna, 2021).

Overall, with the legal prohibitions on witchcraft, wildlife hunting and habitation of public forests as aforesaid, people may only access public forests for any other traditional customary use/benefits other these two in government forests. These permissible uses include: collecting fuelwood, harvesting honey, harvesting herbs for traditional medicine, or accessing such forests (public forests) for socio-cultural and religious purposes such as worship or traditional rites of passage; but not occupying and/or residing in them.

\section{The Legally Permissible Traditional Customary Uses of Wildlife and Forests under Kenyan Law}

As already stated in this paper, while wildlife and forests have from time immemorial had several traditional customary uses, some of these uses are under Kenyan prohibited; while there are others that are expressly allowed, or have no legal prohibition on them; hence are legally permissible and can be enjoyed or practiced. While these uses are permissible, there is still an inherent bar, which is that they cannot be enjoyed or subject to the general prohibition on witchcraft i.e. that provided they are not being exercised in the practice or promotion of witchcraft. The part below discusses these legally permissible traditional customary uses.

\subsection{The Legally Permissible Traditional Customary Uses of Wildlife}

While some wildlife uses cannot be enjoyed in Kenya for reason of legal prohibi- 
tion, there are however other uses that the law has expressly allowed, or has not prohibited and which the Kenyan people can therefore lawfully enjoy in their wildlife (i.e. legally permissible uses). Apparently, the only legally permissible use of wildlife is its non-consumptive use for socio-cultural and spiritual purposes; subject to the existing legal prohibition under the Witchcraft Act, under which witchcraft is prohibited. This in effect means, in Kenya, it is legally permissible to exploit wildlife, provided also that it is not for the practice or promotion of witchcraft.

\section{Non-consumptive Socio-Cultural and Spiritual Uses of Wildlife Other Than For Witchcraft Purposes}

Wildlife has numerous socio-cultural and spiritual uses, hence being an integral constituency of the socio-cultural and spiritual life of many ethnic communities in Kenya. Wild animals were from time immemorial hunted and used for socio-cultural and spiritual purposes such as ceremonies, witchcraft, magic, rites of passage, and even worship. However, this is no longer lawful under the existing laws, particularly where such uses entail the actual killing of wildlife or is for witchcraft. From the year 1977 when the Kenya Government by Legal Notice No. 120 of 1977 aforesaid banned all forms of wildlife hunting in Kenya, it is illegal to kill wildlife. The Witchcraft Act Cap 67 has for its part prohibited witchcraft as well as its practice and promotion.

In this author's opinion therefore, the only traditional customary use of wildlife in Kenya is non-consumptive socio-cultural and spiritual uses and for purposes other than the practice or promotion of witchcraft. These are discussed below and are essentially for symbolism purposes. Notably, some wild animals as discussed below are so revered in some communities that their totemic (sacred), ritualistic and symbolic values are enhanced through a combination of songs, dances, mythology, artistic drawings, paintings, sculpture, carvings, as well as religion. Virtually all ethnic communities in Kenya have a long-standing historical association with wildlife and traditionally have some cultural attachment to certain wild animals (Ipara, 2004). This is manifested in many traditional folklore and folktales over the years; for instance, folklore and folktales about "the cunning hare", "the beautiful guinea fowl", "the slow tortoise", "the mighty lion", "the stealthily leopard" and "the majestic elephant" (Ipara, 2004). The proverbial use of wild animals in songs and stories acts as a reservoir for society's knowledge on wildlife, enhances the stylistic attributes of folklore and folktales, and in some cases symbolizes the cultural significance of certain animals in the community concerned, as will be discussed below.

Besides, some wild animals are totems in certain communities, where they are perceived to be sacred. Totemism is "the designation of a particular animal as a sacred emblem, not to be interfered with (Kameri-Mbote, 2002). There are communities in Africa which believe that the spirits of their dead members and ancestors reside in certain animal species. These species are 'emblem" or totem for such communities and cannot be killed except for cultural rites or in defence 
against an attack by it, in the belief that a misfortune could befall the killer or his family (Ipara, 2004; Sifuna, 2009). This author in a research for another study established that to this day there are tribes in Kenya with their own tribal totem animals, and that these tribes include: the Kikuyu of central Kenya; the Meru, Akamba and Embu of Eastern Kenya; the Abagusii, Abakuria, Abaluhya, Luo and Ateso of western Kenya; the Taita, Mijikenda and Pokomo of the Kenyan Coast; the Kalenjin, Turkana and Maasai of the Rift Valley region (Sifuna, 2009). Some of the totemic wild animals include the leopard, monkey, fox, antelope, elephant, buffalo, crocodile, tortoise and certain species of snakes for instance the cobra, puff adder and python (Sifuna, 2009).

\subsection{The Legally Permissible Traditional Customary Uses of Forests}

\subsubsection{Non-Consumptive Socio-Cultural and Spiritual Uses of Forests, Other Than For Witchcraft Purposes}

In Africa and even Asia, forests have for long not only been used for socio-cultural and religious purposes, but have also from time immemorial been associated with some spirituality. In many indigenous African cultures, forests have for long been used for witchcraft, magic, worship and traditional rites, which though are essentially non-consumptive use forms, are of tremendous sentimental value to the African people. This is a remarkable departure from the traditional African customary wildlife use values that are invariably consumptive in nature (Sifuna, 2009). As reported by this author in an earlier study on wildlife, in the typical traditional African customary perspective with regard to wildlife value, the intrinsic value of wildlife is perceived to be no value at all, and only consumptive wildlife uses and benefits are considered to value (Sifuna, 2012). Conversely, with regard to forestry, the traditional customary benefits are construed in terms of both consumptive and non-consumptive uses. Which is encouraging. Virtually all indigenous communities across Kenya ascribe socio-cultural and spiritual values to forests. Spiritually, forests are also associated with evil spirits (a negative attribute) as well as ancestral spirits (a positive attribute) and as the place of abode of residence of these spirits. In the Luhya community of western Kenya for instance, forests are believed to habour evil spirits and children are discouraged from entering them except in the company of adult family members, and only during day time; never at night. Such mystic attributes of forests are replicated across the entire indigenous ethnic spectrum of Kenya, as they are in virtually all of the country's indigenous ethnic communities.

Unlike in the western civilizations where forests are used for recreation and fun, in the African civilization they are used for serious issues and circumspection. There are however isolated cases in Africa and even Kenya where the venues of some cultural, social and religious ceremonies, festivities and events are located in forests. Largely, forests in the African context have sacred sites for: Cultural rituals, cultural rites e.g rites of passage, worship, intercession, witchcraft, traditional sacrifices, curse ordeals, and even adjudication of disputes. Here 
below are some examples of these uses:

The Mijikenda tribe of the Kenyan coast use the Kaya Forests for sacred purposes such as worship, adjudication of disputes, as well as prosecution and punishment of societal wrongs (Clark, 2011). The Nchuri Ncheke Elders of the Ameru community in Eastern Kenya conduct prayers, witchcraft, curse ordeals, cultural events, and judicial adjudication at shrines (called "nyomba ya njuri" in the local Meru dialect) located in the region's forests such as the Nyambene forest (Gacheri, 2020). Some of their curses, for instance the kithiri curse and the uthiri curse are dreaded in the community and even by the adjoining communities. The kithiri curse for instance, is reported to be irreversible and of dire consequences for the subject, hence it is meted out in the most exceptional cases and for the gravest transgressions. It is reported that from as early as the $17^{\text {th }}$ century to date, the Njuri Ncheke has always adjudicated community issues in Meru and Tharaka Nithi, acting as an ethnic judiciary for the Ameru community; and that their verdicts are even respected by the country's courts of law (Mburugu, 2016).

With regard to use for worship, Lowman has reported that in many parts of the world, before the advent of temples, people worshipped trees or under trees, and even in forests; and gives the example of Ethiopia's "forest churches" as well as India's "prayer forests" (Lowman \& Sinu, 2017). It is also worth noting that it is not just the forests. Even trees and particularly the indigenous ones have some symbolism. While in the traditional African culture some trees are revered and considered sacred or totem, trees are also generally perceived to be a link between the sky and the earth, and even between the spiritual realm and the earth. Just the way electric cables transmit electric currents, trees are perceived to transmit spiritual currents both the holy as well of evil from the earth (from the community) to the spiritual realm.

\subsubsection{Use in Herbal Folk Medicine, Other Than For Witchcraft Purposes}

Trees and forests have been an integral part of herbal folk medicine. Apart from their use for human food and nutrition, the parts of roots, barks, stems and even leaves of trees from forests around the country have been used in treatment and cure of diseases and ailments in humans and domestic stock. Githae (1995) reports that herbal medicines are preferred by the rural folk for reason of being cheaper and more readily available than conventional medicines (pharmaceutical drugs); and for reason that being natural, they unlike pharmaceuticals tend to be less toxic as they do not have toxic preservatives. Apart from use in the treatment of diseases and ailment as aforesaid, herbs are also useful in witchcraft and "black magic". Under the Witchcraft Act Cap 67, this user is illegal. As already discussed above, the Act prohibits the practice and promotion of witchcraft as well as the possession of witchcraft articles and paraphernalia. Therefore, the only lawful and legally permissible use of forest parts in folk medicine is for the beneficial use of treatment and healing, and not harmful use for evil and suffering. Commenting on the importance of traditional medicine in Kenya, Banquar (1995) observes as follows: 
"Traditional herbal medicines play a vital role towards the well-being and development of the rural population in Kenya. Herbal therapy, though still an unwritten science, is well established in the cultures and traditions and has become a way of life for almost 80 percent of the people in Africa. It has been noted that many diseases which could not be cured by the allopathic or other systems of treatment have been cured by traditional medicine."

As reported by Kipkore et al. (2014), traditional medicine (folk medicine) remains an important component of the healthcare in sub-Saharan Africa largely due to the prevailing poverty, inadequate health services and shortage of health workers. Besides, it is based primarily on traditional knowledge systems of the local communities, hence is simple and does not require the technological sophistry of the modern biomedicine. Upretty and Asselin (2012) for their part have reported that medicinal plants have been used in traditional healthcare systems since prehistoric times and are still the most important healthcare source for the vast majority of the population around the world. They further estimate that 70 - 80 percent of people worldwide rely on traditional herbal medicine to meet their primary health care needs. Apart from providing medicinal herbs for traditional/folk medicine, plant extracts from forests are used by pharmaceutical companies in the manufacture of medical drugs (CTA, 1992); hence their use in modern medicine. This traditional herbal medicine can be an important driver in the primary health and even in the curative health of the predominantly poor, less literate and unsophisticated setting of rural Kenya. This is not only for reason of being cheaper and more accessible than biomedicine, but also for reason of being based on traditional knowledge systems that have endemically existed in the local communities for generations. Given that it does not require the technological sophistry of modern medicine, it is more convenient and adapted to the circumstances of the largely traditional setting of rural Kenya. Writing on traditional medicine among the Maasai, Sankan (2006) identifies two parallel systems of traditional medicine, namely, the "genuine medical practice" and the "deceptive medical practice"; and observes that while the former is based on actual traditional knowledge, the latter is based on deceit and trickery, and is meant to exploit and fleece the public. In other words, the latter is a conduit for unjust enrichment.

\subsubsection{Use for Human Food and Livestock Fodder}

Forests are an important source of food for humans and fodder for livestock, hence are important for supplying nutritional needs of humans and livestock. Livestock feed on fodder within the forests and also graze on grass and shrubs in the grazing areas that are located inside the forests, for instance glades the open areas within the forests. For human beings, forests and forest resources have been an important source of food since the hunter-gatherer stage of development where humans survived on hunting and gathering of fruits and other edible plant parts. Thus apart from wood products, there are several non-wood forests products that human eat for nourishment and nutritional needs. These in- 
clude fruits and other edible products.

Under the FCM Act (The Forest Conservation and Management Act of 2016), adjacent forest communities can still enjoy these benefits, but in a structured manner under the Participatory Forest Management (PFM) Model run by the Kenya Forest Service (KFS). Under this programme, local communities in the areas around gazetted state forests may form Community Forest Associations (CFAs) through which they participate in the management of these forests, and also enjoy benefits from them. These benefits comprise the conventional ones as well as the lawful traditional customary benefits such as the ones enumerated above. As already noted in this paper, the use of wildlife and forests in folk medicine (ethnomedicine) in Kenya can be stifled by the legal prohibition on witchcraft and witchcraft-related conduct (Sindiga et al., 1995). Mutungi (1977) has noted that Kenya's Witchcraft Act has a definitional problem with regard to the term "witchcraft" which it has not precisely defined. With an overly positivist judiciary together with an overzealous, corrupt, less literate, and socially insensitive police force such as Kenya's, there is a higher likelihood of this Act being used (actually misused) to stifle folk medicine. This is unlike in the neighbouring country, Uganda, whose Witchcraft Act (Cap 108 Laws of Uganda) is so carefully worded as to avoid such a mischief. The Act in its interpretation section states as follows:

"For purposes of this Act, witchcraft does not include bona fide spirit worship or the bona fide manufacture, supply or sale of native medicines." ${ }^{\prime 10}$

Thairu (1975) has for instance reported that the decline of folk medicine during the colonial era was due to the colonialists associating it with witchcraft and "black magic". This explains why in Kenya, folk medicine started declining at the onset of colonial rule.

\subsubsection{Use for Firewood}

The use of forests and trees for firewood is a typical aspect of the traditional African lifestyle, hence it is a traditional cultural use. While it is an immemorial traditional practice, it has been even in the wake of rapid socio-cultural transformations of modernity and modern lifestyles. With such resilience it is even gradually metamorphosizing into a conventional modern use, that is so amorphous and changing in form, as charcoal is still a form of firewood but in that form being preferably referred to as woodfuel.

A study at the African Center for Technological Studies (ACTS) in the year 2002 found that woodfuel is regarded as the ordinary citizen's energy source, consuming a quarter of an ordinary household's income (Kituyi, 2002). Indeed of all the beneficial uses of wood, the most predominant and endemic one even in traditional African customary setting, is use for firewood/woodfuel. The Kenya Government has estimated that at least $80 \%$ of Kenya's rural households rely on woodfuel either as firewood or charcoal, and that the charcoal industry is a leading

${ }^{10}$ Section 2. 
contributor to job creation, employing approximately 700,000 people and supporting between 2.3-2.5 million dependants (GOK, National Forest Policy 2014). Ototo \& Vlosky (2018) have for their part reported that these two forms of woodfuel (charcoal and firewood) are the main source of energy for heating and cooking for a majority of households in Kenya and generate for over 75 percent of the country's energy requirements. The Government has further estimated that over $80 \%$ of Kenyans rely on wood biomass for their energy requirements, and that biomass comprises about 80 percent of all energy used in the country (GOK, National Forest Policy 2014). Indeed of all the beneficial uses of wood, the most predominant and endemic one even in traditional African custom is use for firewood/woodfuel, and to this date, wood remains an important source of fuel in rural Kenya.

Woodfuel is used for cooking, heating and even as a source of light. The author reminisces his past while growing up in a rural setting of western Kenya. Whenever their tin lamps (called "tove"/"tobe"/"tatoba"/"matikii" in his local luhya dialect) ran out of paraffin, they would resort to fire as a source of light while spreading their bedding, simply charting away, listening to their storytelling grandmother (Taina), or even for study. Wood is also used by the rural folks during funeral night vigils and other rituals as a source of fire and light where they gather tree logs and branches and light them up into bonfire. Such bonfires are meant to provide the light and warmth required by the gathering to socialize and chat away the night. There is abundant folklore on this aspect in many traditional African communities in Kenya such as the Luhya, Luo, Mijikenda and even Kamba communities.

\subsubsection{Use as Raw Material in Construction and Traditional Craft}

Forests have from time immemorial been traditionally used in the African society as a source of raw materials used in construction and even in traditional craft industry. Poles from forests have for long been used and continue being used in the construction of houses. Even in the modern construction industry, poles and timber are used as construction materials. Therefore the use of forest wood products in construction need not be over-emphasized. Apart from being used in fencing, construction of houses, and food granaries, wood from forests is also used in the traditional craft industry in making furniture and even royal items such as royal stools and sceptre (Sifuna, 2021).

\section{Conclusion}

This paper has established that whereas wildlife and forests in Kenya have various conventional uses and values, they also have several traditional customary uses. A common thread running through this genre of uses is that they are largely informal, rudimentary and archaic. Despite so being, they nevertheless are critical in the typical African life and represent the inextricable rudimentary technologically bereft relationship between the African people and their natural resources. These uses are anthropologically unique to the African way of life, hence 
are uses that are typical of the traditional African lifestyle. The paper also established however that some of these traditional customary uses can no longer be enjoyed or exercised in the present day Kenya, for reason of having been prohibited and proscribed by the existing laws. The author identified five such uses, namely: wildlife hunting; use of wildlife and forests in the practice and promotion of witchcraft; use of wildlife in folk medicine; use of wildlife for human food and nutrition; and human habitation of public forests (gazetted state forests). The paper further established that other than these prohibited uses, there are still many legally permissible uses that the people of Kenya can, under the existing laws, enjoy in these two natural resources; for reason of there being no legal prohibition on them or being expressly allowed. As for wildlife, its only legally permissible use in Kenya is use for socio-cultural and spiritual purposes; provided also that they are not for the practice and promotion of witchcraft. With regard to forestry, the followings are the traditional customary uses that are legally permissible under Kenya's existing laws: Socio-cultural and spiritual uses other than for witchcraft; use in folk medicine other than for witchcraft; use for human food and livestock fodder; use for firewood; as well as use as raw material in construction and the traditional craft industry. These are the only lawful and legally permissible traditional customary forestry uses that can be enjoyed under Kenyan law.

Lastly, the author found that Kenya's Witchcraft Act Cap 67 has glaring ambiguities even as to the definition of the term "witchcraft", and as to what acts or conduct that amount to witchcraft. The paper has opined that with an overly positivist judiciary together with an overzealous, corrupt, less literate, and socially insensitive police force such as Kenya's, the likelihood of using (actually misusing) the Witchcraft Act to stifle folk medicine or any other traditional African customary uses of wildlife and forests is even higher. This has the effect of clawing back the legality of many of these legally permissible traditional customary uses. The author recommends that the said Act be urgently reviewed and amended in order to align it with the other laws and particularly the wildlife and forestry legislation. Such alignment will ensure it is not used or misused to stifle the legally permissible uses of wildlife and forests discussed in this paper.

\section{Conflicts of Interest}

The author declares that there are no conflicts of interest regarding the publication of this paper.

\section{References}

Banquar, S. R. (1995). The Role of Traditional Medicine in a Rural Environment. In I. Sindiga, C. Nyaigoti-Chacha, \& M. P. Kanunah (Eds.), Traditional Medicine in Africa (pp. 140-152). Nairobi: East African Educational Publishers Ltd.

Caldecott, J. (1988). Hunting and Wildlife Management in Sarawak. Gland: IUCN.

Clark, W.A. (2011). Clarifying the Spiritual Values of Forest Management. Journal for the Study of Religion, Nature and Culture, 5, 18-38.

CTA (Technical Centre for Agricultural and Rural Co-Operation) (1992). Medicines from 
the Forest. Spore 37. Waginingen: CTA. https://hdl.handle.net/10568/45673

Dasman, P. (1964). Wildlife Biology. Hoboken: John Wiley \& Sons.

Gacheri, J. R. (2020). At the Feet of Njuri Ncheke. Standard Newspaper. https://www.standardmedia.co.ke

Githae, J. K. (1995). Ethnomedical Practice in Kenya: The Case of the Karati Rural Service Centre. In I. Sindiga, C. Nyaigotti-Chacha, \& M. P. Kanunah (Eds.), Traditional Medicine in Africa (pp. 55-63). Nairobi: East African Educational Publishers Ltd.

GOK (2014). The National Forest Policy.

GOK (2020a). Ministry of Wildlife and Tourism, Kenya Wildlife Policy Sessional Paper No. 1 of 2020 .

GOK (2020b). Ministry of Environment and Forestry, Draft National Forest Policy 2020.

Hakimzumwami, E. (2000). Community Wildlife Management in Central Africa: A Regional Review. Evaluating Eden Series, Discussion Paper No. 10. International Institute for Environment and Development.

https//www.pubs.iied.org/sites/default/files/pdfs/migrate/7804IIED.pdf

Harako, R. (1984). Religion World of Mbuti Pyignies: Molimo and Baketi. In J. Itani, \& T. Yoneyama (Eds.), The Studies on African Cultures (pp. 137-164), Kyoto: Academia Schuppankai.

Ipara, H. (2004). Resources Management Systems: A Study of the Isukha Community of Western Kenya. D. Phil Thesis, Eldoret: Moi University.

Kameri-Mbote, P. (2002). Property Rights and Biodiversity Management in Kenya. Nairobi: ACTS Press.

Kasere, S. (1996). Campfire: Zimbabwe's Tradition of Caring' United Nations-Non Governmental Liason Service (UN-NGLS). Voices of Africa, No. 6: Sustainable Development Part 2. https://www.digitallibrary.un.org/record/23774? In=en

Kenya Forest Service (KFS) (2018a). Gazetted Forests in Counties as at February 2018. Nairobi.

Kenya Forest Service (KFS) (2018b). KFS Strategic Plan 2018-2022. Nairobi.

Kenya National Bureau of Statistics (KNBS) (2019). National Population Census Report.

King, S., \& Burgess, A. (2000). Nutrition for Developing Countries. London: Oxford University Press.

Kipkore, W., Wanjohi, B., Rono, H., \& Kigen, G. (2014). A Study of the Medicinal Plants Used by the Marakwet Community in Kenya. Journal of Ethnobiology and Ethnomedicine, 10, Article No. 24. https://doi.org/10.1186/1746-4269-10-24

Kituyi, E. (2002). Lost Opportunities: Woodfuel Data and Policy Development Concerns in Kenya. Energy Policy Position Paper. African Centre For Technological Studies (ACTS). Nairobi: ACTS Press.

Krunk, H. (2002). Hunter and Hunted: Relationships between Carnivores and People. Cambridge: Cambridge University Press. https://doi.org/10.1017/CBO9780511614996

Legal Notice No. 120 of 1977 The Wildlife (Conservation and Management) (Prohibition on Hunting of Game animals) Regulations.

Legal Notice No. 171 of 1999 Suspending Timber Harvesting in Kenya.

Lowman, M. D., \& Sinu, P. A. (2017). Can the Spiritual Values of Forest Inspire Effective Conservation? Bioscience, 67, 688-690. https://doi.org/10.1093/biosci/bix057

Mbiti, J. S. (1969). African Religions and Philosophy. New York: Praeger.

Mburugu, K. N. (2016). Resolving Conflict Using Indigenous Institutions: A Case Study of Njuri-Ncheke of Ameru, Kenya. International Journal of Science Arts and Commerce, 


\section{1, 18-33.}

Muriuki, J. N. (1996). Cooperation or Conflict: Managing Scarce Resources of Africa: A Case for Community Wildlife Conservation in Kenya. Mimeo.

Mutungi, O. K. (1977). The Legal Aspects of Witchcraft in East Africa: With Particular Reference to Kenya. Nairobi: East African Literature Bureau.

Norton-Griffiths, M. (2000) Wildlife Loses in Kenya: An Analysis of Conservation Policy. Natural Resource Modeling, 13, 13-34. https://doi.org/10.1111/j.1939-7445.2000.tb00026.x https://www.researchgate.net/publication/227532075 wildlife loses in\%20 Kenya An Analysis of Conservation Policy

Ogendo, R. B. (1972). Industrial Geography of Kenya. Nairobi: East African Publishing House.

Ototo, G., \& Vlosky, R. P. (2018). An Overview of the Forest Sector in Kenya. Forest Products Journal, 68, 6-14.

Overseas Development Administration (ODA) (1996). Africa Wildlife Policy Consultations. Final Report of the Consultation. London: ODA.

Reuben, J. (1973). Kenya in Pictures. https://www.amazon.com//Kenya-Pictures-Joel-Reuben/dp/0806911174

Ruigu, G. M. (1988). Seed Industry in Kenya: Evolution, Current Status and Prospects. http://erepository.uonbi.ac.ke/handle/11295/39766

Sankan, S. S. (2006). The Maasai. Nairobi: Kenya Literature Bureau.

Shaw, J. (1985). Introduction to Wildlife. New York: McCraw-Hill Science.

Sifuna, N. (2009). Legal and Institutional Arrangements for Wildlife Damage in Kenya and Botswana. PhD Thesis, Johannesburg: University of the Witwatersrand, South Africa.

Sifuna, N. (2012). The Future of Traditional Customary Uses of Wildlife in Present Africa: A Case Study of Kenya and Botswana. Advances in Anthropology, 2, 31-38. https://doi.org/10.4236/aa.2012.21004

Sifuna, N. (2021). The Fate of Aboriginal Habitation of Gazetted State Forests in Present Day Kenya: A Case Study of the Agitation by the Ogiek and Sengwer Traditional Communities. Advances in Anthropology, 11, 99-127. https://doi.org/10.4236/aa.2021.112008

Sindiga, I., Nyaigotti-Chacha, C., \& Kanunah, M. P. (1995). Traditional Medicine in Africa. Nairobi: East African Educational Publishers Ltd.

Takirambudde, P. N. (1988). The Role of Law in Commercial and Industrial Expansion: The Case of Botswana, Lesotho and Swaziland. In J. B. Ojwang, \& J. W. Kabeberi (Eds.), Law and the Public Interest. Occasional Paper No. 52 (p. 15). Nairobi: Institute of Development Studies (IDS), University of Nairobi.

Thairu, K. (1975). The African Civilization. Nairobi: East African Literature Bureau.

UPretty, Y., \& Asselin, H. (2012). Traditional Use of Medicinal Plants in the Boreal Forest of Canada: Preview and Perspectives. Journal of Ethnobiology and Ethnomedicine, 8, Article No. 7. https://doi.org/10.1186/1746-4269-8-7

Wantrup, S. V. C. (1952). Resource Conservation: Economics and Policies. Berkley and Los Angeles: University of California Press.

Yamaguchi, R. (2014). The Baka as "Champions" of Witchcraft: Representations in the Ambivalent Relationship between the Baka and the Bakwele in South-Eastern Cameroon. Africa Study Monographs, 47,121-141.

https://www.jam-bo.africa.kyoto-u.ac.jp/asm suppl/abstracts/pdf/ASM s47/8.Yamagu chi.pdf 


\section{Legislation}

The Constitution of Kenya (2010). Nairobi: Kenya Government Printer.

The Forest Conservation and Management Act of 2016 (Act No. 34 of 2016).

The Forests Act of 2005 (Act No. 7 of 2005) (Now Repealed).

The Mining Act of 2012, Cap 306 Laws of Kenya.

Wildlife Conservation and Management Act of 1976 (As Amended in 1989), Cap 376 Laws of Kenya (Now Repealed).

Wildlife Conservation and Management Act of 2013 (Act No. 47 of 2013).

Witchcraft Act Cap 67 Laws of Kenya.

Witchcraft Act Cap 108 Laws of Uganda. 